\title{
Aeromonas enteropelogenes and Aeromonas ichthiosmia Are Identical to Aeromonas trota and Aeromonas veronii, Respectively, as Revealed by Small-Subunit rRNA Sequence Analysis
}

\author{
M. D. COLLINS, ${ }^{*}$ A. J. MARTINEZ-MURCIA, AND J. CAI \\ Department of Microbiology, AFRC Institute of Food Research, \\ Reading RG6 $2 E F$, United Kingdom
}

\begin{abstract}
The 16S rRNA gene sequences of the type strains of Aeromonas enteropelogenes and Aeromonas ichthiosmia were determined by polymerase chain reaction direct sequencing in order to clarify their interrelationships with other aeromonad species. On the basis of $16 \mathrm{~S}$ rRNA gene sequence analysis, $A$. enteropelogenes and $A$. ichthiosmia were found to be identical to Aeromonas trota and Aeromonas veronii, respectively.
\end{abstract}

Identification of species within the genus Aeromonas has undergone major improvements over the past decade, primarily as a result of extensive chromosomal DNA-DNA pairing studies (e.g., references 3 to 5 and 9). Recently, we reported the results of a systematic investigation into the interspecific relationships of aeromonads by $16 \mathrm{~S}$ rRNA gene sequence analysis $(7,8)$. Although most Aeromonas species were found to be distinct on the basis of sequence analysis, several inconsistencies with the relatedness of aeromonads as discerned from DNA-DNA pairing were observed (7). In this article, we report an analysis of the $16 \mathrm{~S}$ rRNA gene sequences of the two recently validated species Aeromonas ichthiosmia (12) and A. enteropelogenes (11) and note yet another example of possible discordance with DNA-DNA pairing.

Strains of $A$. enteropelogenes (DSM $6394^{\mathrm{T}}$ ) and $A$. ichthiosmia (DSM 6393 ${ }^{\mathrm{T}}$ ), obtained from the Deutsche Sammlung von Mikroorganismen (Braunschweig, Germany), were grown in nutrient broth (Oxoid Ltd.) at $30^{\circ} \mathrm{C}$, and cells were harvested in late exponential phase. DNA was extracted by the method of Lawson et al. (6). Polymerase chain reaction amplification and direct sequence analysis of rRNA genes were performed as previously described (7). Determined 16S rRNA sequences were aligned with those of other aeromonad species $(7,8)$, and a phylogenetic tree was produced by the neighbor-joining method (10).

The determined partial 16S rRNA gene sequences consisted of between 1,490 and 1,532 nucleotides, representing approximately 98 to $99 \%$ of the total rRNA molecule. A phylogenetic tree depicting the relationship of $A$. enteropelogenes and $A$. ichthiosmia to other recognized aeromonad species and DNA homology groups is shown in Fig. 1. The 16S rRNA gene sequence of $A$, ichthiosmia DSM $6393^{\mathrm{T}}$ was found to be identical to that of the type strain of $A$. veronii (ATCC 35624). Similarly, the type strains $A$. enteropelogenes DSM 6394 and $A$. trota ATCC 49657 displayed 100\% 16S rRNA gene sequence identity.

In an earlier article, we reported that the relationship between Aeromonas species derived by $16 \mathrm{~S}$ rRNA sequencing generally correlated well with the results of DNA-DNA reassociation, although several discrepancies between the two approaches were noted (7). The finding of identical $16 \mathrm{~S}$

\footnotetext{
${ }^{*}$ Corresponding author.
}

rRNA gene sequences in $A$. ichthiosmia and $A$. veronii appears to add to this discordance. The species $A$. ichthiosmia was described by Schubert et al. (12) for some $A$. sobria-like aeromonads isolated from surface water. $A$. ichthiosmia was reported to be distinct from $A$. veronii on the basis of DNA-DNA reassociation (60\% homology [12]). The presence of indistinguishable 16S rRNA gene sequences in $A$. ichthiosmia and $A$. veronii may be due to lack of sensitivity of rRNA in separating very closely related species (examples of this phenomenon have been noted in other taxa [see references 1 and 2]). However, it should be noted that the DNA-DNA hybridization study of Schubert et al. (12) did not include a determination of the thermal stability of reassociated DNA (see recommendation in reference 13). The separate specific status of $A$. ichthiosmia and $A$. veronii must therefore remain in serious doubt. At present, little can be concluded from the finding of identical 16S rRNA gene sequences in the species $A$. enteropelogenes and $A$. trota. $A$. enteropelogenes was described by Schubert et al. (11) to accommodate some arbutin-negative $A$. sobria-like psychrotrophic aeromonads originating from human stools. Although $A$. enteropelogenes was reported to be different from $A$. hydrophila, $A$. sobria, and $A$. veronii by DNA-DNA reassociation, comparative studies were not performed with $A$. trota (11). The results of the present sequence analysis, however, indicate that these species are genealogically very closely related. DNA-DNA hybridization studies are clearly necessary in order to determine the genospecific relationship between $A$. enteropelogenes and $A$. trota.

rRNA sequencing is an immensely powerful tool for determining the interrelationships of organisms, but it is now apparent that this method often fails to discriminate between closely related species $(1,2,7)$. Currently, the definition of bacterial species is based upon chromosomal DNA-DNA relatedness ( $\geq 70 \%$ homology with a $\Delta T_{m}$ of 0 to $5^{\circ} \mathrm{C}$ [see reference 13]). It is unlikely that a comparable species definition based on rRNA sequences (e.g., percent relatedness or number of nucleotide changes) will be possible because of high overall sequence conservation of the rRNA molecule, its relatively low information content, and different rates of sequence change between lineages. The strength of rRNA sequencing will continue to be the construction of stable genealogically based classifications above the species level. In the case of conflict between the two approaches (e.g., identical rRNA sequences but different species by 


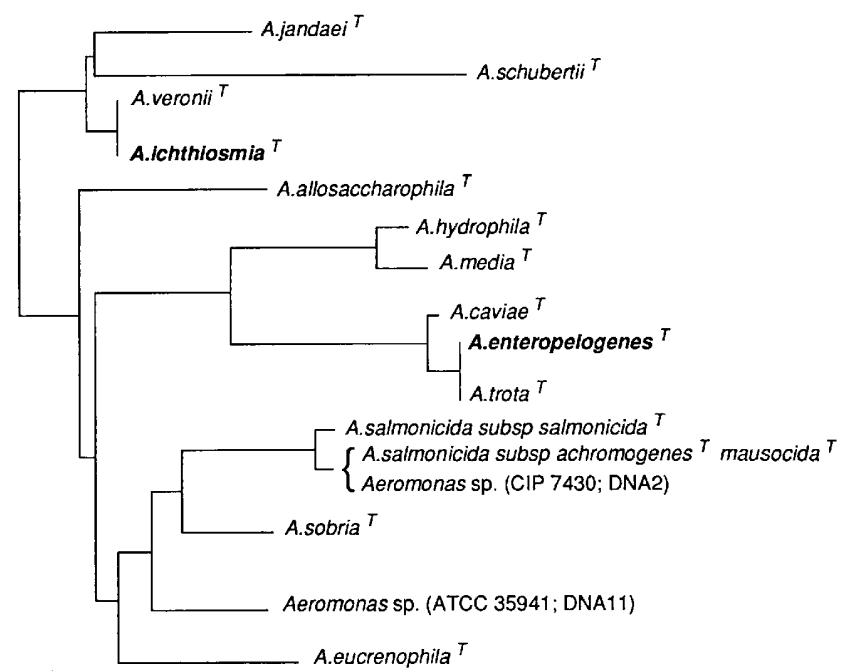

FIG. 1. Phylogenetic tree, constructed by the neighbor-joining method, showing the interrelationships of $A$. enteropelogenes, $A$. ichthiosmia, and other aeromonad species.

DNA-DNA reassociation), the results of chromosomal DNA-DNA relatedness should be taken as definitive.

Nucleotide sequence accession numbers. The rRNA primary sequences determined in this study have been deposited in the EMBL Data Library under accession numbers X71121 (A. enteropelogenes) and X71120 (A. ichthiosmia).

This work was supported by a research grant from the Ministry of Agriculture, Fisheries and Food.

We are grateful to $\mathbf{M}$. Altwegg (University of Zürich) and A. M. Carnahan (University of Maryland) for providing strains to confirm sequence analyses.

\section{REFERENCES}

1. Ash, C., J. A. E. Farrow, M. Dorsch, E. Stackebrandt, and M. D. Collins. 1991. Comparative analysis of Bacillus anthracis, Bacillus cereus, and related species on the basis of reverse transcriptase sequencing of $16 \mathrm{~S}$ rRNA. Int. J. Syst. Bacteriol. 41:343-346.

2. Fox, G. E., J. D. Wisotzkey, and P. Jurtshuk, Jr. 1992. How close is close: $16 \mathrm{~S}$ rRNA sequence identity may not be sufficient to guarantee species identity. Int. J. Syst. Bacteriol. 42:166-170.

3. Hickman-Brenner, F. W., G. R. Fanning, M. J. Arduino, D. J. Brenner, and J. J. Farmer III. 1988. Aeromonas schubertii, a new mannitol-negative species found in human clinical specimens. J. Clin. Microbiol. 26:1561-1564.

4. Hickman-Brenner, F. W., K. L. MacDonald, A. G. Steigerwalt, G. R. Fanning, D. J. Brenner, and J. J. Farmer III. 1987. Aeromonas veronii, a new ornithine decarboxylase-positive species that may cause diarrhea. J. Clin. Microbiol. 25:900-906.

5. Kuijper, E. J., A. G. Steigerwalt, B. S. C. I. M. Schoenmakers, M. F. Peeters, H. C. Zanen, and D. J. Brenner. 1989. Phenotypic characterization and DNA relatedness in human fecal isolates of Aeromonas spp. J. Clin. Microbiol. 27:132-138.

6. Lawson, P. A., S. E. Gharbia, H. N. Shah, and D. R. Clark. 1989. Recognition of Fusobacterium nucleatum subgroups Fn-1, Fn-2 and Fn-3 by ribosomal RNA gene restriction patterns. FEMS Microbiol. Lett. 65:41-46.

7. Martinez-Murcia, A. J., S. Benlloch, and M. D. Collins. 1992. Phylogenetic interrelationships of members of the genera Aeromonas and Plesiomonas as determined by $16 \mathrm{~S}$ ribosomal DNA sequencing: lack of congruence with results of DNA-DNA hybridizations. Int. J. Syst. Bacteriol. 42:412-421.

8. Martinez-Murcia, A. J., C. Esteve, E. Garay, and M. D. Collins. 1992. Aeromonas allosaccharophila sp. nov., a new mesophilic member of the genus Aeromonas. FEMS Microbiol. Lett. 91:199-206.

9. Popoff, M. Y., C. Coynault, M. Kiredjian, and M. Lemelin. 1981. Polynucleotide sequence relatedness among motile Aeromonas species. Curr. Microbiol. 5:109-114.

10. Saitou, N., and M. Nei. 1987. The neighbour-joining method: a new method for reconstructing phylogenetic trees. Mol. Biol. Evol. 4:406-425.

11. Schubert, R. H. W., M. Hegazi, and W. Wahlig. 1990. Aeromonas enteropelogenes species nova. Hyg. Med. 15:471-472.

12. Schubert, R. H. W., M. Hegazi, and W. Wahlig. 1990. Aeromonas ichthiosmia species nova. Hyg. Med. 15:477-479.

13. Wayne, L. G., D. J. Brenner, R. R. Colwell, P. A. D. Grimont, O. Kandler, M. I. Krichevsky, L. H. Moore, W. E. C. Moore, R. G. E. Murray, E. Stackebrandt, M. P. Starr, and H. G. Trüper. 1987. Report of the ad hoc committee on reconciliation of approaches to bacterial systematics. Int. J. Syst. Bacteriol. 37:463-464 